[Vicino Oriente XVI (2012), pp. 275-302]

\title{
EGYPTIAN AND EGYPTIANIZING OBJECTS FROM EB I-III TELL ES-SULTAN/ANCIENT JERICHO
}

\author{
Maura Sala - Sapienza University of Rome
}

\begin{abstract}
I rapporti tra Egitto e Levante nel IV-III millennio a.C. sono variamente illustrati nella recente letteratura. Manca tuttavia ad oggi una presentazione dettagliata dei materiali egiziani ed egittizzanti provenienti da Tell es-Sultan, antica Gerico. Per la sua posizione strategica al centro di un importante crocevia e la sua prossimità a materie prime essenziali, Gerico assunse sin dagli inizi dell'età del Bronzo un ruolo rilevante nelle relazioni intessute dall'Egitto faraonico con il Levante meridionale. Attraverso l'analisi dei reperti egiziani ed egittizzanti rinvenuti a Gerico si delineano le dinamiche dei rapporti commerciali e culturali instauratisi tra Egitto e Palestina alla fine del IV millennio a.C., e per tutta la prima fase dell'urbanizzazione palestinese, che una parte ragguardevole ebbero nella fioritura dei primi centri urbani nella regione*.
\end{abstract}

Keywords: Tell es-Sultan/Jericho; Egyptian and Egyptianizing finds; Early Bronze Age; trade and cross-cultural contacts

\section{INTRODUCTION}

Since the beginning of Early Bronze Age (henceforth EBA) ${ }^{1}$ both exotic raw materials and manufactured items (as palettes, maceheads, stone vessels, shell and stone beads, and pottery vases) were imported from Egypt in Southern Levant. In EB IA exchange was still limited and desultory, land-based, and primarily centred on some key sites (as Southern Levantine coastal settlements, Jericho in the inland, or Byblos to the north). ${ }^{2}$ Nevertheless, since the EB IB, a steady network of relationships and trades was established, and supported by the presence of Egyptian outposts in Southern Palestine (as 'Ain Besor and Tell es-Sakan), ${ }^{3}$ that is communities of specialists in a land still politically unorganized, with the main aim of supplying Egypt with foreign products locally not available. Concurrently, a range of Egyptian imported or local Egyptianizing goods spread in

* This study moves from the researches carried out by the Author within the publication of volumes ROSAPAT 01 and 05 (Nigro 2005; 2010), which include a thorough examination of EB I and EB II layers, architecture and material at Tell es-Sultan/ancient Jericho. I wish to thank Prof. L. Nigro for having allowed me to study and reassess Egyptian and Egyptianizing finds from the EBA proto-urban and urban phases at Tell es-Sultan.

1 Contacts and exchanges were actually active between Egypt and Southern Levant since the Late Chalcolithic Period, i.e. the beginning of the $4^{\text {th }}$ millennium BC/Naqada IB/C Period, although at first in a small scale and sporadic way: Chalcolithic inhabitants of Southern Levant controlled in fact a range of resources and raw materials (copper and agricultural products, as wine and olive oil) of interest to Egyptians. Conversely, Egyptian artefacts, like a few pottery vessels, Nilotic shell pendants, flint knives, stone palettes and maceheads, start to be intermittently attested to in the Palestinian territory: Lovell 2008; Mączyńka 2008; Braun - van den Brink 2008, 644-650; Braun 2011, 105-108.

2 Davies 1981; de Miroschedji 2002, 40-41; Nigro 2007, 9-10, 32-33, 37-38; Braun - van den Brink 2008, 651659; Braun 2011, 108-110.

3 De Miroschedji et al. 2001; de Miroschedji 2002, 41-45; Braun - van den Brink 2008, 659-672; Braun 2011, 112-119. Egyptian presence in Southern Levant in the late $4^{\text {th }}$ millennium BC is further illustrated by the discovery of a monumental dromos tomb at Tell el-Khuweilfeh (Levy et al. 2002, 424-428; Braun - van den Brink 2008, 658-659). 
Southern Levant, mostly in south-western Palestine, where the phenomenon of Egyptianizing pottery became predominant ( $§ 2.5$.), and a wealth of prestige objects started to be traded in.

Egyptian presence in Southern Levant retreated at the beginning of EB II, possibly in connection with the establishment of the Palestinian urban society and the emergence of local polities exercising a stronger territorial control, and, on the other hand, as a consequence of the intensification of royal maritime trades putting the overland route out of use. ${ }^{4}$ Nevertheless, Egyptian agents supervising economic interests of Egyptian royal courts were still active in EB II Palestine, ${ }^{5}$ accomplishing trade and diplomatic tasks between the Pharaonic state and the Palestinian rulers in charge of procuring stuffs that Egypt needed: oils and resins, as well as wine. The retrieval of Palestinian objects (mainly ceramic containers) in the coeval necropolises of Egypt (I-II Dynasties), points to the presence of a continuous and enduring exchange. ${ }^{6}$ The direct exploitation of the Palestinian land by Egyptian colonists was thus replaced by royal Egyptian agents residing in Canaan, dealing with the Palestinian rulers, and exchanging with them luxury objects against local products required by the Pharaonic state. Palestinian elites on their own adopted and looked for valuable Egyptian artefacts as insignia of their emerging status, because of their exotic raw material, sophisticated technique of manufacturing and faraway origin.

The pattern of Egyptian-Palestinian relationships continued the same dynamics in EB III, with Egyptian emissaries in the Palestinian territory (as it has been hypothesised for Khirbet Yarmouk), ${ }^{7}$ and the Palestinian urban ruling class adopting Egyptian commodities as forms of royal and elite display, in order to reinforce social hierarchies and their political governance. It is not by chance that in EB II-III prestige Egyptian items are mainly found in temple, palatial and rich tombs contexts (implying elite acquisition of such goods), where they were transmitted as well with an intrinsic heirloom value. In this phase the sea route to Byblos took indisputably the dominant role in the Egyptian-Levantine trade, and the economic relationships between Egypt and Western Asia were reorganized. Notwithstanding this, direct relationships between Egypt and Southern Levant (both overland and maritime) did not cease, neither in EB II, nor in EB III: Egyptian funerary inscriptions also suggest that commercial expeditions (and sometimes also military ventures) were sent from Egypt to Palestine during the Old Kingdom. ${ }^{8}$

4 De Miroschedji 2002, 45-47. Tyre and Ashqelon are candidates as possible EB II ports, until seafarers gained experience to move farther afield up to Byblos since the late Second Dynasty.

5 The presence of an Egyptian representative has been hypothesised at Khirbet Kerak, where an Egyptian jug and a local jug inscribed with an Egyptian hieroglyphic inscription were found in EB II layers: Greenberg Eisenberg 2002, 214-221; Greenberg et al. 2012, 96; Sowada 2009, 36-37. Khirbet Kerak was in fact a pivotal centre for the trade in oils and resins from Northern Palestine.

6 Especially Light-Faced Painted Ware ("Abydos Ware”), and Red-Polished jugs witness wine and perfumes exports from Palestine towards Egypt, as well as pattern-combed jars testify to the export of olive oil.

7 Sowada 2009, 109, 127.

$8 \quad$ Helck 1971, 16-17; de Miroschedji 2012. 


\section{THE CORPUS OF EGYPTIAN OBJECTS IN EB I-III SOUTHERN LEVANT}

Imported Egyptian manufactured items attested to in EBA Southern Levant include mainly luxury objects, either traded as gifts and diplomatic exchanges, or acquired by local leaders as insignia of status for their value: prestige exotic trinkets contribute to elite differentiation at the dawn of Palestinian urbanization. Egyptian artefacts also inspired a local production of Egyptianizing objects, above all in the EB II-III urban phase, intended to satisfy a local high-level consumption related to the presence of a developing stratified society.

Three main categories of high status objects were exported during the late $4^{\text {th }}-3^{\text {rd }}$ millennium BC from Egypt to Southern Levant, identified as Egyptian according to their typology/shape, raw material, ${ }^{9}$ and technique of manufacture: stone palettes ( $§ 2.1$.), stone maceheads ( $(2.2$.$) , and stone vessels ( § 2.3$.). They all belonged to a pattern of luxury gift exchange or prestige trade items between elites in antiquity. Egyptian beads and personal ornaments, primarily in carnelian, steatite, frit/faïence or Nilotic shells, are present as well, mostly in funerary contexts $(\S 2.4$.). Finally, a series of Egyptian and Egyptianizing ceramics from Southern Levant ( $\S 2.5$.), among which the "lotus vase" typology present since the beginning of EB I until EB IIIB, further illustrates EBA Egyptian-Palestinian contacts. Conversely, perishable goods imported from Egypt, like textiles, basketry, wooden and bones items (as toilette articles), ${ }^{10}$ are often difficult to be recorded in the archaeological evidence. ${ }^{11}$ They are not quoted at Tell es-Sultan; thus they are not dealt within this paper.

\subsection{Palettes}

Cosmetic siltstone/greywacke palettes were a prominent feature of Egyptian material culture since the $4^{\text {th }}$ millennium BC (above all in funerary contexts) ${ }^{12}$ and they started decreasing towards the end of the First Dynasty. By the Naqada IIIB Period, a simpler form of square/rectangular palette with incised lines around the edge becomes prominent, while concurrently a few palettes begin to feature relief carving and to be linked to the expression of elite cultural and ceremonial values, becoming at times royal objects of display and insignia of power (as in the case of stone maceheads; $\S 2.2.)^{13}$

Egyptian siltstone palettes, in their commoner shapes, appear in Southern Levantine EB I-III settlements and funerary contexts, holding a prestigious character deriving from their exotic origins and craftsmanship. ${ }^{14}$ They were imported in small quantities since the

9 A large range of stones, i.e. geological resources, was available in ancient Egypt, such as red and white and black and white breccia, grey-green siltstone, creamy travertine, black and white diorite porphyry, mottled limestone, rock crystal and dark basalt (Klemm - Klemm 2008). Except for limestone, rock crystal and basalt, other materials were not locally available in Palestine.

10 To be mentioned, the bone comb, the dagger handle and the carved breast cones from Sanctuary A, at 'Ai/etTell (Hennessy 1967, 71; Callaway 1972, 302-304).

11 Sowada 2009, 237-238

12 Kroeper 1996.

13 Petrie 1953, 1, pls. A-K; Wengrow 2006, 41-44, 140-142.

14 Siltstone is not known from Palestine, and the closest source were the Wadi Hammamat quarries in Upper Egypt (Klemm - Klemm 2008, 307-309; Teeter [ed.] 2011, 70). 
beginning of EB I, as attested by the specimens retrieved at Gaza, Azor (Tomb 4), Tell el'Areini, ${ }^{15}$ in the Wadi Ghazzeh, ${ }^{16}$ and at Jericho (§ 3.1.). An Egyptian palette was also found in a late EB IB/EB II tomb in the cemetery near 'Ain Assawir, together with other Egyptian objects (all apparently high status imports). ${ }^{17}$ Imported palettes belonged to different types, mainly animal-shaped items, among which fish was a most popular theme (like the Gaza specimen testifies); ${ }^{18}$ or rectangular types bordered by one or two parallel incised lines (like the Jericho and Assawir specimens attest), ${ }^{19}$ frequently with a hole drilled at the top.

The Palestinian corpus of Egyptian siltstone palettes increases in the EB II-III, primarily in the square/rectangular typology, when actually their use started decreasing in the Egyptian motherland: their diffusion in Southern Levant appears thus much later than the floruit of the type in Egypt, ${ }^{20}$ as testified by the palette from Tell el-Khuweilfeh (and a handful of siltstone fragments); ${ }^{21}$ the four specimens from Bab edh-Dhra'22 (along with Egyptianizing items made from local stones); ${ }^{23}$ the fragmentary item from Numeira; ${ }^{24}$ the diorite palette from ' $\mathrm{Ai} ;{ }^{25}$ and the three specimens from Khirbet Kerak. ${ }^{26}$ One more siltstone palette, of a slightly different type, comes from EB II Arad, ${ }^{27}$ and two from EB III Khirbet Yarmouk. ${ }^{28}$ Moreover, since EB II, items imported from Egypt were more often

15 Sowada 2000, 1532; de Miroschedji 1992; Ben-Tor 1975a, 28, fig. 14:1, pl. 21:2-3; Sowada 2009, 228.

16 A siltstone palette was found in Chalcolithic/EB IA layers, together with two limestone maceheads and Gerzean flint blades: MacDonald - Starkey - Harding 1932, 10-11, pls. XXIII:28, XXVIII:7.

17 Yannai 2002, 338, 340-341, fig. 22.1:22; Braun - van den Brink 2008, 671; Teeter (ed.) 2011, fig. 12.23:1

18 Teeter (ed.) 2011, 160, cat. n. 6; Wengrow 2006, fig. 5.4. Animal-shaped palettes spread in Egypt above all during the Naqada II Period, roughly corresponding to Palestinian EB IA.

19 Teeter (ed.) 2011, 199, cat. n. 51. Egyptian palettes tend to become simpler in shape since the beginning of Naqada III/ Dynasty 0/Palestinian EB IB. Squared palettes with a border incised on one face with one to three lines appear since the end of Naqada II, and become the most commonly encountered type in Naqada III.

20 Different hypotheses have been advanced to explain this chronological divergence, suggesting that they could be either heirlooms from an earlier period, products of tombs robbing, or results of long-term exchange mechanisms (Sowada 2000, 1531-1534; 2009, 243-244.)

21 Jacobs 1996.

22 Two from Field XVI (Reg. n. 1262 and 2924: Rast - Schaub 2003, 294, fig. 10.39:2, 400, fig. 12.6:3-4), one from Charnel Houses A21 (Rast - Schaub 1989, 343; Wilkinson 1989, 455, fig. 261:7), and one from Charnel Houses A51 (Rast - Schaub 1989, 384-385; Wilkinson 1989, 454, fig. 261:3). See also Sowada 2009, 95-97, fig. 18, pl. 13 .

23 Two specimens from Charnel Houses A22 (Reg. n. 1900, 3364: Sowada 2000, 1529-1530, fig. 1c, 1e), three from Charnel Houses A51 (Wilkinson 1989, 452-454, fig. 261:1-2, 4), two from Charnel Houses A41 (Wilkinson 1989, fig. 261:5-6). See also Sowada 2009, 95-97, fig. 18, pl. 13.

24 Sowada 2000, 1528-1529, fig. 3b; 2009, 93-94, pl. 13.

25 Marquet-Krause 1949, 60, pl. 38.482.

26 Greenberg - Eisenberg 2002, 214, fig. 13.2.

27 Amiran et al. 1978, 55, pl. 68:21.

28 Sowada 2000, 1531; 2009, 104-105, fig. 19, pl. 14. Outstanding (and up to now isolated) is the fragment of the ceremonial siltstone palette with an Egyptian high-quality relief carving (a hand grasping a was sceptre and 'ankh), found at Khirbet Kerak in an EB III context (although the excavators deem it redeposited after it was broken), next to the "Circles Building". Prior to this discovery, examples with relief decorations were known only within Egypt itself, and their use seems to have been essentially confined to the early Egyptian elites during the Dynasty 0 period: the pictorial decoration on the Khirbet Kerak fragment is in fact consistent 
placed side by side with Egyptianizing pieces locally manufactured, as specimens from Bab edh-Dhra' and Jericho clearly illustrate ( $\$ 4.1$.$) : the Egyptian production inspired a local$ tradition of palettes fabrication, almost all plain, roughly rectangular, with holes drilled in the top centre, made from regional stones and manufactured by Canaanite craftsmen for local elites members.

\subsection{Maceheads}

Maceheads are attested to in Egypt since the Chalcolithic Period. They progressively evolved from actual weapons to symbols of power and prestige of the king, and since the Naqada III Period they became purely ceremonial objects. With this purpose they spread also in the Levant since the EB I ( $\$ 3.2$.), as ritual and status-related insignia. They were realized in a variety of different stones, as marble, calcite and limestone, but the lack of detailed analyses of raw material makes often difficult to ascertain if they were either imported, Egyptian influenced or purely local artefacts, even if their accurate finish often suggests an Egyptian production. Like the palettes, also the maceheads ceased to be produced in Egypt during the $3^{\text {rd }}$ millennium BC, but they spread in Southern Levant for the whole EB II-III urban period: maceheads made of travertine, marble and granite (all of them not available in Palestine) of certain Egyptian origin were found in EB II-III Charnel Houses at Bab edh-Dhra', as well as at Tell el-Far'ah North, Megiddo, Beth Shan, Tell Abu Kharaz, and Jericho ( $§ 4.2 .$, 5.2.).

\subsection{Stone vessels}

Egyptian ateliers manufactured stone vessels since the Pre-dynastic Period, as a wide variety of geological resources was available either in Egypt or in its desert periphery. They were devoted to different functions: daily use, ritual purposes as temple offerings, and funerary contexts. ${ }^{29} \mathrm{~A}$ great variability of stones was use in the earliest periods (among which porphyry, diorite, breccia, serpentine, gabbro, granite, travertine, calcite, rock crystal, limestone and basalt), but during the Old Kingdom travertine, calcite and limestone became dominant, while more exotic stones were reserved for special consumers, such as the royal family and high ranking officials. Most of the Egyptian stone vessels were uninscribed; just a small percentage (found essentially in royal burials and temples) carried hieroglyphic inscriptions naming Egyptian pharaohs or members of the royal family, or, less frequently, aristocratic private individuals (the latter ones mainly associated with funerary contexts).

Egyptian stone vessels were widely traded in Eastern Mediterranean, and they are present also in Southern Levant as trade items, elite gifts exchanges or temple offerings, with a marked increase since the beginning of the $3^{\text {rd }}$ millennium $\mathrm{BC}, \mathrm{EB} \mathrm{II},{ }^{30}$ as specimens from Arad, ${ }^{31}$ Tell el-'Areini, Tell el-Far'ah North, ${ }^{32}$ 'Ain Assawir, ${ }^{33}$ Khirbet Yarmouk, ${ }^{34}$

with the prestigious Egyptian examples dating to Dynasty 0: Greenberg - Wengrow - Paz 2010; Greenberg et al. 2012, 96-97.

29 For corpora of Egyptian stone vessels see Aston 1994; Lilyquist 1995.

30 Sparks 2003, 40-48; Sowada 2009, 48-50.

31 Amiran et al. 1978, 57, pl. 77:1-2; Sowada 2009, 45, fig. 5c. 
Megiddo, ${ }^{35}$ and Jericho ( $§ 4.3$.) testify, although their intrinsic prestige and heirloom value make difficult to fix the actual time of arrival. They were widely distributed also in EB III, from the renown collection of vessels from "Sanctuary A" at "Ai/et-Tell, ${ }^{36}$ to the noteworthy corpus from Khirbet Yarmouk, ${ }^{37}$ and scattered specimens from Megiddo, ${ }^{38}$ Tell ed-Duweir, ${ }^{39}$ Tell el-'Areini, ${ }^{40}$ and Bab edh-Dhra' ${ }^{41}$ They appear mainly associated with temple and palatial structures ${ }^{42}$ thus testifying the elite acquisition and valuable nature of these goods. Bowls and platters dominate the whole assemblage, indicating that such items were traded not as containers, but rather as prestige commodities in their own right, either sent as royal gift (not by chance they are often found in temple and palatial contexts), exchanged by Egyptian agents, or acquired by local elites as status objects. Unfortunately specimens from Southern Levant are all uninscribed, but Canaan had no high-quality local hard stone industry in the $3^{\text {rd }}$ millennium $\mathrm{BC}$, hence Egyptian imports are easily identified on the base of raw material and manufacturing technique. ${ }^{43}$

\subsection{Beads and personal ornaments}

An eclectic range of stones was used in both Egypt and Southern Levant for the production of amulets and beads. Bi-conical barrel and disk-shaped beads made of amethyst, orange-red carnelian, ${ }^{44}$ dark blue glazed steatite, serpentine and faïence found in Palestine may be feasibly of Egyptian origins. A trade in Red Sea and Nilotic shells from Egypt also started as early as the Chalcolithic Period, and continued in the EBA.

\subsection{Pottery}

The most significant instance is the widely debated case of Egyptian and Egyptianizing pottery (i.e. Palestinian locally produced ceramic in imitation of Egyptian forms) in EB IB

2 Sowada 2009, 48-49, fig. 4a-b

3 Yannai 2002, 338, fig. 22.1:22.

4 De Miroschedji et al. 1988, 88, pl. 48:9-10; Sowada 2009, 49-50, figs. 4c, 5a.

35 A fragment of an Egyptian calcite jar was found in stratum XVIII: Loud 1948, pl. 258:1; Hennessy 1967, 60-61.

36 Marquet-Krause 1949, 16-21, 29; Hennessy 1967, 69-70; Amiran 1970; Callaway 1972, 299-302. Two calcite bowls were found also in the Temple on the Acropolis of Phase A (Amiran 1970, 175-179).

37 Ben-Tor 1975b, 72, note 26; de Miroschedji et al. 1988, 88, pl. 48:11-12; Sowada 2009, 105-109, figs. 19-21, pl. 15. 'Ai and Khirbet Yarmouk were the largest EB II-III centres in Southern Palestine. At Khirbet Yarmouk Egyptian stone vessels were found mainly in proximity of the so-called "White Building" and Palace B.

38 Loud 1948, pl. 262:7.

39 Tufnell 1958, 75, 253, pl. 26:10 (even if the contexts of retrieval of both fragments are not indicative).

40 Sowada 2009, 103, fig. 20.

41 Two small fragments of Egyptian stone vessels from the tell (Lee 2003, fig. 21.5:2-3) were found together with a pink alabaster cylinder seal (Lapp 2003, 541-543, fig. 18.16), and another cylinder seal made of chlorite (Lapp 2003, 547-550, fig. 18.21).

42 Sala 2008, 17-18, 69, 235-236, 302-303; Sowada 2009, 110, 216-218

43 Egyptianizing stone vessels workshops seem to become active in the Levant only since the Late Bronze Age (Sparks 2003).

44 Deposits of carnelian exist in Southern Levant, but to date no evidence of utilisation of such resources has been found (Braun - van den Brink 2008, 671). 
centres of south-western Palestine, ${ }^{45}$ among which the "lotus vase" category is a most notable example $(\S$ 3.3.). The presence of Egyptian vessels in Palestine continues in occasional ways in the following EB II, as a few vessels from Arad, ${ }^{46}$ Aphek, ${ }^{47}$ Khirbet Kerak, ${ }^{48}$ Megiddo, ${ }^{49}$ and Tell Abu Kharaz ${ }^{50}$ testify; and definitely decreases in the following EB III, as illustrated by an apparently isolated example from Bab edh-Dhra ' ${ }^{51}$ Conversely Egyptianizing vessels continued to be manufactured in the "lotus vases" type, as attested to by the specimens retrieved in Temple of level J-4 at Megiddo, ${ }^{52}$ in EB IIIB Sanctuary A at 'Ai/et-Tell, ${ }^{53}$ and in EB IIIB Palace B at Khirbet al-Batrawy, which represents a relevant evidence of still active Egyptian contacts, influence or reminiscence, up to this remote easternmost EB III city of Transjordan. ${ }^{54}$

\section{EGYPTIAN AND EGYPTIANIZING OBJECTS AT EB I TELL ES-SULTAN}

EB I was a period of growing contacts between Egypt and Southern Levant. A substantial Egyptian connection is testified to at Tell es-Sultan since EB I by a conspicuous number of Egyptian and Egyptianizing finds retrieved in EB IA-B layers, both on the tell and in the nearby necropolis. ${ }^{55}$

The increasing presence of Egyptian prestige commodities from both the tell and the necropolis during mature EB IB, in the incipient urban phase of the Jerichoan settlement, along with appearing Egyptianizing items, looks a distinguished feature of Tell es-Sultan, and hints at the role played by the Egyptian connections as a factor stimulating the early urban formation in the settlement. ${ }^{56}$

\subsection{Palettes}

Egyptian stone palettes are attested to at EB I Tell es-Sultan both in an elongated type, known from a specimen retrieved on the tell by Sellin and Watzinger which bears some incisions (fig. 1) ${ }^{57}$ and above all in the square type bordered by two incised lines, with a perforated hole at the top, known from two specimens: one made of a black stone from a late EB IA context, retrieved by J. Garstang in the North-Eastern Trench (level VII; fig.

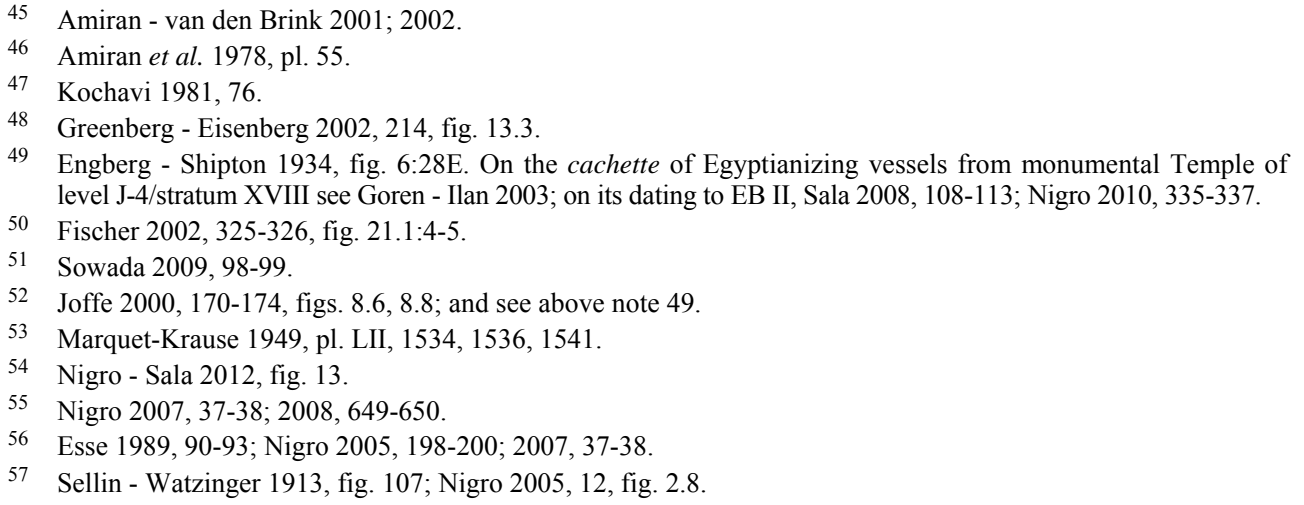


2:1) ${ }^{58}$ and another one made of siltstone from an EB IB context, retrieved by K.M. Kenyon in Trench III (phase liiia; fig. 2:2). ${ }^{59}$ The two Jerichoan specimens are strictly consistent with the diffusion of the same type in Egypt between late Naqada II/early Naqada III Period, as a contemporary specimen made of siltstone from Abadyia and dating back to the Naqada IIIA clearly testifies, ${ }^{60}$ and they represent the earliest attestation of this typology in Palestine, alongside with the animal-shaped palettes more common in the earlier period (as the Gaza specimen testifies), and in Egypt during the Naqada II Period (§ 2.1.).

A third EB IB palette, probably of local manufacture, was retrieved by Kenyon in Trench III (phase lxi-lxiia; fig. 3) ${ }^{61}$

\subsection{Maceheads}

Twelve maceheads, ten from the tell and two from the necropolis, were retrieved in EB I contexts at Tell es-Sultan, in both spherical and pear-shaped typology (fig. 4). ${ }^{62}$ Unfortunately, absence of detailed analyses on raw material makes difficult to ascertain if they were Egyptian imports or local artefacts, but calcite ("Egyptian alabaster") and marble identifications reported in Kenyon's reports might point to an Egyptian origin of most of them. ${ }^{63}$

J. Garstang found a spherical (fig. 4:1) and a pear-shaped macehead (the latter made of calcite; fig. 4:5 $)^{64}$ from an EB IA layer (level VII) at the eastern bottom of his NorthEastern Trench, just to the east of EB I Shrine 420. A third limestone macehead was retrieved in the EB IB layer of Tomb A (fig. 4:6). ${ }^{65}$ The latter find is particularly notable because it was associated to a dead (n. 24) buried in a distinguished position: the deceased in fact had been buried lying on his back with crossed legs; and in between the legs the macehead was found. The distinguished posture in the final deposition of the dead (for which a possible connection with a priestly role has been hypothesized) might be a characterization of the social role played by the deceased within the community, also emphasized by the presence of the macehead. ${ }^{6}$

58 Garstang et al. 1936, pl. XXXVI:26; Nigro 2005, 34, fig. 3.28. I thank Dr. Giulia Tucci for redrawing of palettes illustrated in figs. 2-3

59 Holland 1982, 559, fig. 226:16, Reg. 1955

60 Teeter (ed.) 2011, 199, n. cat. 51.

61 Reg. 1874: Dorrell 1983, 559, fig. 230:13.

62 Both typologies are attested since EB I, while the elongated pear-shaped type appear at Tell es-Sultan only in the following EB III (contra the specimens retrieved in EB IB contexts at Horvat 'Illin Tahtit and Tell Abu Kharaz, see below).

63 See catalogue in $\S 7$. Unfortunately the use of term "alabaster" in older literature is often misleading: the socalled "Egyptian alabaster", i.e. calcite (also named calcite-alabaster) or travertine, differs in fact from general alabaster, i.e. gypsum, that is softer and whiter, and available also in Southern Levant (Aston - Harrell - Shaw 2000, 21,-22, 59-60; Klemm - Klemm 2008, 147; Shaw 2010, xv, 11-30).

64 Inv. ns. 3677, 4112: respectively Garstang et al. 1936, pl. XXXVI:24-25; Nigro 2005, 16-18, 34, fig. 3.28; 2008, 649-650.

65 Garstang 1932, pl. VII:5.

66 Polcaro 2005, 59-64, fig. 3.50; Nigro 2008, 652. A comparison is offered by EB IA Tomb A65 at Bab edhDhra': here, in the southern chamber, a single body was buried in primary deposition with bent legs, and a macehead was found in the nearby shaft (Rast - Schaub 1989, 83-85): the uniqueness of the primary burial, 
A second specimen from Jericho necropolis was found by K.M. Kenyon in Tomb K2: the object, made of calcite, shows the compressed pear-shaped form typical of EB IB maceheads (fig. 4:8). ${ }^{67}$ This type of status object (both in the spherical and pear-shaped type) has been found in several other EB I tombs, as Tomb 3 at Tell Far'ah North, ${ }^{68}$ Tomb 4 at Azor, ${ }^{69}$ and in the numerous samples in the cemetery of Bab edh-Dhra', where in EB IA it appears a constant element of funerary equipment (in Tombs A72, A71, A76, A68, A81, A67, A65): ${ }^{70}$ in Tomb A65 a calcite macehead of Egyptian origin is an indicator of the increasing trade contacts with Egypt during EB I, including the exchange of prestige commodities which reached also the Palestinian inland.

K.M. Kenyon found other eight maceheads, basically made of calcite or marble, and thus of presumable Egyptian origin, in different sector of the tell (fig. 4:3-4, 7). ${ }^{71}$ Finally, a spherical macehead from Sellin and Watzinger's excavations (of unspecified stone) must be quoted (fig. 4:2). ${ }^{72}$

In EB I other Egyptian specimens were found in coastal Southern Levantine sites, as the calcite macehead from Horvat 'Illin Tahtit in EB IB $;{ }^{73}$ at Megiddo, where an Egyptian discshaped black and white breccia macehead was retrieved in the EB IB temple compound (locus 4047) of stratum XIX (together with a local limestone specimen) $;{ }^{74}$ at Beth Shan, where many fragments of both spherical and pear-shaped maceheads were found in EB I layers (but the stone of fabrication is not specified) ${ }^{75}$ up to the Jordan Valley, at Pella and Tell Abu Kharaz. ${ }^{76}$

\subsection{Egyptianizing pottery}

EB I Egyptian connections are finally testified to by the presence of two Egyptianizing "lotus vases" from EB IA layers in Kenyon's Tomb K1 (fig. 5:2) and Tomb A114 (fig. 5:1). ${ }^{77}$ Occurrence of Egyptianizing pottery is a phenomenon that affects, even massively, sites in the south-western Palestine in the last quarter of the $4^{\text {th }}$ millennium $\mathrm{BC}$, when during late EB IB in Palestinian centres as Tell el-'Areini and Tel Ma'ahaz, Egyptianizing pottery comes to represent up to $80 \%$ of the ceramic repertoire.

which spreads in the cemetery of Bab edh-Dhra' only in the following EB IB, might indicate in this context a special social role of the deceased, as well as the presence of the macehead points to, a possible leading role within the framework of an extended family group.

67 Kenyon 1965, 8-27. The first phase of Tomb K2, dated to EB IA, also contained hundreds of necklace beads, made of different materials of possible Egyptian provenance: most of the beads is made of carnelian, but many shells beads were also present. Unfortunately, no detailed analysis of shells is provided to determine their provenance (Kenyon 1965, 8-27).

De Vaux 1949, 108

Ben-Tor 1975a, 23, fig. 12:7, pl. 21:1.

Rast - Schaub 1989, 289-294.

71 Reg. 684, 685, 1827, 1959.22, 1959.30, 1959.31, 3383: Holland 1983, 804-806, fig. 365:1-2, 6.

72 Sellin - Watzinger 1913, fig. 109.

73 Braun et al. 2001, 75-76.

74 Loud 1948, pl. 270:2-3

75 Braun 2004, pls. III:26-27, VI:26-27.

76 Bourke et al. 1994, 91-93, fig. 7.1; Fischer 2002, 327-328, 330, fig. 21.2:1-2.

77 Respectively, Kenyon 1960, fig. 17:23, and Kenyon 1965, fig. 12:6; Sala 2005, 178. 
The presence of two Egyptianizing vessels at EB IA Jericho, before the spread of the phenomenon in Southern Palestine, combined with the discovery of an Egyptian palette and six calcite/white limestone maceheads from EB IA contexts, is thus once more meaningful of the Egyptian-Jerichoan connections since the Pre-dynastic Period, and testifies to the early establishment of relationships thanks to the centrality of the area of the Oasis, located in a strategic position in the communication and exchange system, and close to essential raw materials, such as sulfur, bitumen and salt from the Dead Sea.

\subsection{Beads and personal ornaments}

The picture of Egyptian imports is completed by an amount of carnelian and frit/faïence beads of presumable Egyptian provenance from EB I tombs in the nearby necropolis. ${ }^{78}$

\section{EGYPTIAN AND EGYPTIANIZING OBJECTS AT EB II TELL ES-SULTAN}

In EB II the presence of Egyptian material at Tell es-Sultan from both the site and the necropolis apparently decreases; but the manufacturing of local imitations (such as Egyptianizing stone palettes) progressively increases, and corroborates the existence of enduring contacts, and most probably trade relationships, between the new-born city of Jericho and Pharaonic Egypt. At the beginning of the urban period, the richest families of the city of Jericho were able to import Egyptian items (namely maceheads as status insignia); on the other hand, local craftsmen started to imitate Egyptian luxury commodities in order to satisfy an increasing high-level consumption. Thus Egyptian imports were often substituted by local replicas of Egyptian status symbols or personal ornaments.

In Kenyon's excavations, early EB II strata provided some very interesting items: three Egyptianizing stone palettes from the northern plateau on the tell, and one more palette from Tomb D12, along with a possible Egyptian barrel-shaped macehead, and two Egyptian limestone vessels from Squares EIII-IV.

\subsection{Palettes}

Three Egyptianizing stone palettes were found in EB II contexts on the tell: two from Trench II (phases liv-lv and lviii; fig. 6:2), ${ }^{79}$ and one from Squares EIII-IV (Phase F; fig. 6:1). ${ }^{80}$ They all exhibit a plain rectangular shape with slightly rounded corners, contrasting the Pre- and Protodynastic Egyptian palettes retrieved at Jericho itself in EB I layers, which show a sharp square shape decorated by two parallel lines incised along the border, and the Egyptian siltstone palettes still attested to in EB II-III contexts at Tell el-Khuweilfeh, Khirbet Kerak, Bab edh-Dhra' and Numeira (§ 2.1.). It seems thus that EB II stone palettes from Jericho, though inspired by Egyptian prototypes, were products of local craftsmanship. They find meaningful comparisons in contemporary EB II-III specimens

78 Five carnelian beads from Tomb A124 (Kenyon 1965, fig. 6:12), 163 carnelian beads from Tomb K1 (Kenyon 1965, 30-31), 506 carnelian beads from Tomb K2 (Kenyon 1965, 19-21; Talbot 1983, 794-796), and more than 100 frit/faïence beads from Tomb K1 (Talbot 1983, 794-796).

79 Reg. 2630 (Dorrell 1983, 559), and Reg. 2632, roughly finished and thicker (Dorrell 1983, 559, pl. 21c).

80 Reg. 1197: it was bigger and finely made, with a smoother, worn-down area in the centre of each face (Dorrell 1983, 559, fig. 230:12). 
from the necropolis of Bab edh-Dhra', plain, rectangular and with a hole drilled in the top centre, most likely Egyptian influenced, but locally manufactured. ${ }^{81}$

A further Egyptianizing stone palette was found in Tomb D12 (fig. 6:3):82 it is likewise roughly rectangular, with slightly rounded corners, and perforated by a hole at one end.

\subsection{Maceheads}

A barrel-shaped macehead, made of a black stone and finely worked, was found in Squares EIII-IV (Phases K-J; fig. 7): ${ }^{83}$ this kind of status symbol (icon of the leader) thus maintained its popularity in the period, and even more in the following EB III (§ 5.2.). It was most probably an Egyptian importation, because of the employed material, and the careful technique of manufacture and finish.

At Megiddo an Egyptian pear-shaped calcite macehead was retrieved in the EB II temple compound of stratum XVIII on the eastern slope; ${ }^{84}$ two Egyptian well-finished calcite maceheads were found in EB II contexts at Tell Abu Kharaz, along with two local unfinished limestone items; ${ }^{85}$ and an Egyptian travertine macehead was found at EB II Tell el-Far'ah North. ${ }^{86}$ Finally, a pear-shaped macehead was found at Beth Shan in stratum XIII, but its stone is not specified. ${ }^{87}$

\subsection{Stone vessels}

Two high-quality polished limestone bowls fragments of likely Egyptian origin were also found in EB II layers in Squares EIII-IV: the rim of a fine bowl (from Phase H; fig. 8 ) ${ }^{88}$ and half of an inner finely polished oval bowl with lug handles (from Phase Gi). ${ }^{89}$

The two Jerichoan bowls are consistent with the appearance of this kind of Egyptian commodity (mainly bowls) in many EB II Palestinian centres, since the beginning of the $3^{\text {rd }}$ millennium BC, while they seem still absent in previous EB I (§ 2.3.).

\section{EGYPTIAN AND EGYPTIANIZING OBJECTS AT EB III TELL ES-SULTAN}

At the present state of research, at EB III Jericho Egyptian objects are in essence represented by the category of maceheads, basically made of calcite and marble, and of a highly polished manufacture, nonetheless illustrated by a quite eclectic array of types. In addition, an Egyptianizing palette, and a quantity of carnelian and frit/faïence beads from EB III tombs in the nearby necropolis, can be quoted. The nature of Egyptian-Jerichoan

81 Wilkinson 1989, 452-456, fig. 261:1-2, 4-6.

82 Kenyon 1960, 125, fig. 40:3, Reg. 353.

83 Reg. 1449. This object was considered a spindle whorl by M. Wheeler (Wheeler 1982, 630, fig. 256:2), but according to T.A. Holland it was a macehead (Holland 1983, 806).

84 Loud 1948, pl. 270:4.

85 Respectively, Fischer 2002, 328, 330, fig. 21.2:3, 5, and 21.2:4, 6 .

86 Sowada 2009, 232.

87 Braun 2004, pl. VI:19.

88 Reg. 1619: Dorrell 1983, 554, fig. 229:17; Sowada 2009, 49, fig. 5b.

89 Reg. 1507: Dorrell 1983, 554, pl.19a; Sowada 2009, 49. From Squares EIII-IV a carnelian bead was also found (Talbot 1983, fig. 362:5), in addition to those from Tomb A127 (Kenyon 1960, 92, fig. 28), and Tomb D12 (Kenyon 1960, 125-126; Talbot 1983, 796-798). 
contacts should not change, and the urban elite still purchased exotic prestige insignia and trinkets, as symbols of power and authority.

\subsection{Palettes}

An Egyptianizing palette, comparable in morphology to item 2632 (§ 4.1.; fig. 6:2), was found in an EB III context in Site $\mathrm{H},{ }^{90}$ but no further indication is offered in the reports.

\subsection{Maceheads}

Ten maceheads from the tell, ${ }^{91}$ and one from the necropolis,,${ }^{92}$ were retrieved during Kenyon's excavations (fig. 9:2-10). To these, a pear-shaped macehead from Sellin and Watzinger's excavations (of unspecified stone) must be added (fig. 9:1). ${ }^{93}$

Elongated pear-shaped maceheads dominate in EB III Jericho (fig. 9:1-5), as well as in the examples from Bab edh-Dhra', where two Egyptian maceheads were retrieved in EB III Charnel Houses: one from Charnel House A21, and another one made of granite from Charnel House A51. ${ }^{94}$ The Jerichoan specimens appear basically made of calcite or marble: a complete elongated pear-shaped macehead from Site $\mathrm{H}$, made of a pink streaky marble, is most remarkable (figs. 9:4, 10). A quite elongated spherical item from Trench I was also found (fig. 9:8), along with two barrel-shaped maceheads from Squares EIII-IV (Phase Ci), of an unrecorded stone, but highly polished (fig. 9:6-7). Similarly, at Megiddo an Egyptian spherical marble-like macehead from Palace 3177, and two Egyptian calcite pear-shaped and barrel-shaped maceheads from Temple 4040 were found in EB III contexts (together with three limestone specimens). ${ }^{95}$ Finally, two cylindrical maceheads, one made of an unrecorded black stone, were found in Kenyon's Trench I (fig. 9:9-10).

Above all in this mature EB III phase it is difficult to ascertain if maceheads were either Egyptian imported or Egyptianizing, since material is often unrecorded, and it was also possible that raw materials were imported from Egypt and locally processed. Anyhow, the sophisticated technique of manufacture and careful finish point to a probable Egyptian origin of most of them.

\subsection{Beads and personal ornaments}

An amount of disk and barrel-shaped carnelian and frit/faïence beads from EB III Tombs F2 and F $3^{96}$ can be classified as EB III Egyptian imports on the basis of their raw material of production.

90 Reg. 3267: Dorrell 1983, 559.

91 Reg. 311, 444, 611, 710, 1048, 1116, 1593, 1781, 2922, 3194: Holland 1983, 804-806, fig. 365:3-5, 7, 10-11, 13; Wheeler 1982, 630, fig. 256:1

92 Reg. 151: Kenyon 1960, 171, fig. 66:4.

93 Sellin - Watzinger 1913, fig. 110.

94 Wilkinson 1989, 459-460, fig. 263:4.

95 Loud 1948, pl. 270:5-10. A limestone macehead was found also at EB III Beth Shan in stratum XII (Fitzgerald 1935, 19-20, pl. X:23). Two more maceheads were found at EB III Tell el-Hesi (Bliss 1894, figs. 81-82), and a handful of maceheads was retrieved at Tell ed-Duweir (Tufnell 1958, pl. 26:1-4), but no detailed information is reported.

96 Kenyon 1960, 155-156, fig. 55, 172-173, fig. 65. Many other stone beads are not identified. 


\section{CONCLUSIONS}

EBA collection of Egyptian and Egyptianizing objects from Tell es-Sultan illustrates the enduring trade and cultural contacts between Egypt and the site through the whole EB I-III, and, at the same time, the evolutions and progressions of such relations within the political and socio-economic framework of the earliest Levantine urban societies.

After the peak of exchanges between Egypt and Southern Levant in the late $4^{\text {th }}$ millennium BC, Canaan continued supplying Egypt with commodities during the EB II-III, even if, since the beginning of the $3^{\text {rd }}$ millennium $\mathrm{BC}$, previously strong links had to compete with the maritime Byblos network.

Egyptian EB II-III objects in Southern Levant are, in fact, often scantily documented, but, as the overview on the Jerichoan Egyptian and Egyptianizing items testifies, more should exist in the archaeological record. Moreover, possibly perishable Egyptian exports (like, for instance, linen textiles) might be taken into consideration, in addition to the durable stone or pottery goods. At the same time, as the Jerichoan palettes attest, EB II-III Canaanite craftsmen started also a local production of Egyptian-inspired commodities, possibly to satisfy the increasing request of emerging Palestinian urban elites within a developing stratified society.

Thus, if during the Old Kingdom Egyptian interests moved decisively to the northern Levantine coast, and the sea route towards Byblos was well-travelled, Egyptian-Palestinian contacts did not cease and, in particular, relations of elite patronage continued to be cultivated in Southern Levant until the end of EB III, as the Egyptian ceremonial maceheads from EB III Jericho still testify. During the EB II-III urban period EgyptianPalestinian relationships became more faceted, not only commercial, but above all diplomatic. A certain concentration of Egyptian imported items can be surely noted in southern and central Palestine, at Khirbet Yarmouk, 'Ai and Jericho itself, but main urban centres to the north, like Megiddo or Khirbet Kerak, were likewise involved in these elite exchanges, the purpose of which was ensured the Egyptian state with valuable resources (as, for instance, copper from the Wadi Feinan), achieved through exchanges with the most powerful local Canaanite ruling elites. Sampling of combed ware found in Old Kingdom Egypt reveals, moreover, that containers came from Southern Levant until the Sixth Dynasty, indicating a still alive trade of stuffs and (liquid) commodities between the regions. Only the collapse of the earliest Palestinian urban society at the end of the $3^{\text {rd }}$ millennium $\mathrm{BC}$ brought to an end such prosperous and well rooted relations between these two neighbouring and harmonising countries.

\begin{tabular}{|c|c|c|}
\hline \multicolumn{3}{|c|}{ EGYPTIAN AND EGYPTIANIZING OBJECTS FROM TELL ES-SULTAN } \\
\hline \multirow[t]{2}{*}{ ARCHAEOLOGICAL PERIOD } & \multicolumn{2}{|c|}{ FINDS } \\
\hline & EGYPTIAN OBJECTS & EGYPTIANIZING OBJECTS \\
\hline EB I & $\begin{array}{l}3 \text { palettes } \\
12 \text { maceheads ( } 10 \text { from the tell } \\
\text { and } 2 \text { from the necropolis) }\end{array}$ & $\begin{array}{c}1 \text { palette } \\
2 \text { lotus vases }\end{array}$ \\
\hline EB II & $\begin{array}{c}1 \text { macehead } \\
2 \text { stone vessels }\end{array}$ & 4 palettes \\
\hline EB III & $\begin{array}{l}12 \text { maceheads ( } 11 \text { from the tell } \\
\text { and } 1 \text { from the necropolis) }\end{array}$ & 1 palette \\
\hline
\end{tabular}

Tab. 1: Summary table of Egyptian and Egyptianizing objects from Tell es-Sultan. 


\section{Catalogue}

\section{EARLY BRONZE I}

Type: palette from Garstang's excavations (inv. number 3678) [fig. 2:1]

Dating: EB IA

Material: black stone (type unrecorded)

Context of retrieval: tell, Garstang's North-Eastern Trench, locus 270

Stratum: level VII

State of preservation: fragmentary

Dimensions: preserved length $6.7 \mathrm{~cm} \times$ preserved

width $5.5 \mathrm{~cm} \times$ thickness $0.9 \mathrm{~cm}$

Bibliography: Garstang et al. 1936, pl. XXXVI:26

Type: palette from Kenyon's excavations

(inv. number 1955) [fig. 2:2]

Dating: EB IB

Material: siltstone

Context of retrieval: tell, Trench III

Stratum: XV.liia

State of preservation: fragmentary

Dimensions: preserved length $4.4 \mathrm{~cm} \times$ preserved

width $3.3 \mathrm{~cm} \times$ thickness $0.6 \mathrm{~cm}$

Bibliography: Holland 1982, 559, fig. 226:16

Type: palette from Kenyon's excavations

(inv. number 1874) [fig. 3]

Dating: EB IB

Material: stone (type unrecorded)

Context of retrieval: tell, Trench III

Stratum: XVI.1xi-lxiia

State of preservation: complete

Dimensions: length $13.5 \mathrm{~cm} \times$ width $18.5 \mathrm{~cm} \times$ thickness $1.5 \mathrm{~cm}$

Bibliography: Dorrell 1983, 559, fig. 230:13

Type: palette from Sellin \& Watzinger's excavations [fig. 1]

Dating: EB I

Material: stone (type unrecorded)

Context of retrieval: tell, northern plateau

Stratum: unrecorded

State of preservation: complete

Bibliography: Sellin - Watzinger 1913, fig. 107

Type: macehead from Garstang's excavations (inv. number 3677) [fig. 4:1]

Dating: EB IA

Material: stone (type unrecorded)

Context of retrieval: tell, Garstang's North-Eastern

Trench, locus 270

Stratum: level VII

State of preservation: complete

Dimensions: length $4.6 \mathrm{~cm} \times$ diameter $5.3 \mathrm{~cm}$

Bibliography: Garstang et al. 1936, pl. XXXVI:25
Type: macehead from Garstang's excavations (inv. number 4112) [fig. 4:5]

Dating: EB IA

Material: calcite/Egyptian alabaster

Context of retrieval: tell, Garstang's North-Eastern

Trench, locus 270

Stratum: level VII

State of preservation: fragmentary

Dimensions: preserved length $4.6 \mathrm{~cm} \times$ diameter $4.7 \mathrm{~cm}$

Bibliography: Garstang et al. 1936, pl. XXXVI:24

Type: macehead from Sellin \& Watzinger's excavations [fig. 4:2]

Dating: EB I

Material: stone (type unrecorded)

Context of retrieval: tell, northern plateau

Stratum: unrecorded

State of preservation: complete

Dimensions: length $4.5 \mathrm{~cm} \times$ diameter $5.4 \mathrm{~cm}$

Bibliography: Sellin - Watzinger 1913, fig. 109

Type: macehead from Garstang's excavations (inv. number 567) [fig. 4:6]

Dating: EB IB

Material: white stone (type unrecorded)

Context of retrieval: necropolis, Tomb A

Stratum: layer $3 / 24 d$

State of preservation: complete

Dimensions: preserved length $5.3 \mathrm{~cm} \times$ diameter $5 \mathrm{~cm}$

Bibliography: Garstang 1932, pl. VII:5

Type: macehead from Kenyon's excavations

(inv. number 1827) [fig. 4:4]

Dating: EB IB

Material: calcite/Egyptian alabaster

Context of retrieval: tell, Trench III

Stratum: XV.lvii

State of preservation: fragmentary

Dimensions: length $4.5 \mathrm{~cm} \times$ diameter $5.5 \mathrm{~cm}$

Bibliography: Holland 1983, 804, fig. 365:1

Type: macehead from Kenyon's excavations (inv. number 685) [fig. 4:7]

Dating: EB IB

Material: calcite/Egyptian alabaster

Context of retrieval: tell, Square MI

Stratum: XIX.xciv

State of preservation: fragmentary

Dimensions: length $5.3 \mathrm{~cm} \times$ diameter $5.6 \mathrm{~cm}$

Bibliography: Holland 1983, 804, fig. 365:2

Type: macehead from Kenyon's excavations (inv. number 684) [fig. 4:3]

Dating: EB IB 
Material: cream-coloured banded marble Context of retrieval: tell, Square MI

Stratum: XIX.xciv

State of preservation: fragmentary

Dimensions: length $4.3 \mathrm{~cm} \times$ diameter $5.5 \mathrm{~cm}$ Bibliography: Holland 1983, 804, fig. 365:6

Type: macehead from Kenyon's excavations (inv. number 111) [fig. 4:8]

Dating: EB IA

Material: calcite/Egyptian alabaster

Context of retrieval: necropolis, Tomb K2

Stratum: Phase I

State of preservation: complete

Dimensions: length $3.6 \mathrm{~cm} \times$ diameter $3.8 \mathrm{~cm}$

Bibliography: Kenyon 1965, fig. 5:8

Type: macehead from Kenyon's excavations (inv. number 1959.22)

Dating: EB IA

Material: white stone

Context of retrieval: tell, Squares EIII-IV

Stratum: Phase V-T

State of preservation: almost complete

Dimensions: length $6.8 \mathrm{~cm} \times$ diameter $6.4 \mathrm{~cm}$

Bibliography: Holland 1983, 804

Type: macehead from Kenyon's excavations (inv. number 1959.31)

Dating: EB IA

Material: pinkish-coloured stone (type unrecorded)

Context of retrieval: tell, Squares EIII-IV

Stratum: Phase V

State of preservation: almost complete

Dimensions: length $8 \mathrm{~cm} \times$ diameter $6.8 \mathrm{~cm}$

Bibliography: Holland 1983, 804

\section{EARLY BRONZE II}

Type: palette from Kenyon's excavations (inv. number 1197) [fig. 6:1]

Dating: EB II

Material: stone (type unrecorded)

Context of retrieval: tell, Squares EIII-IV

Stratum: Phase Fi

State of preservation: complete

Dimensions: length $16.5 \mathrm{~cm} \times$ width $11.5 \mathrm{~cm} \times$ thickness $1.5 \mathrm{~cm}$

Bibliography: Dorrell 1983, 559, fig. 230:12

Type: palette from Kenyon's excavations (inv. number 2630)

Dating: EB II

Material: stone (type unrecorded)

Context of retrieval: tell, Trench II

Stratum: XVI.liv-lv

State of preservation: fragmentary
Type: macehead from Kenyon's excavations (inv. number 1959.30)

Dating: EB IA

Material: white limestone

Context of retrieval: tell, Squares EIII-IV

Stratum: Phase Xi

State of preservation: fragmentary

Dimensions: length $3.2 \mathrm{~cm} \times$ diameter $4.4 \mathrm{~cm}$

Bibliography: Holland 1983, 804

Type: macehead from Kenyon's excavations (inv. number 3383)

Dating: EB IB

Material: limestone

Context of retrieval: tell, Trench II

Stratum: XV.lia

State of preservation: fragmentary

Dimensions: diameter $6.3 \mathrm{~cm}$

Bibliography: Holland 1983, 804

Type: lotus vase [fig. 5:1]

Dating: EB IA

Material: pottery

Context of retrieval: necropolis, Tomb A114

Dimensions: diameter $20 \mathrm{~cm}$

Bibliography: Kenyon 1960, fig. 17:23

Type: lotus vase [fig. 5:2]

Dating: EB IA

Material: pottery

Context of retrieval: necropolis, Tomb K1

Dimensions: diameter $10 \mathrm{~cm}$

Bibliography: Kenyon 1965, fig. 12:6

Dimensions: thickness $1.2 \mathrm{~cm}$

Bibliography: Dorrell 1983, 559

Type: palette from Kenyon's excavations

(inv. number 2632) [fig. 6:2]

Dating: EB II

Material: stone (type unrecorded)

Context of retrieval: tell, Trench II

Stratum: XVI.lviii

State of preservation: complete

Dimensions: length $10 \mathrm{~cm} \times$ width $6.5 \mathrm{~cm} \times$

thickness $2 \mathrm{~cm}$

Bibliography: Dorrell 1983, 559, pl. 21:c

Type: palette from Kenyon's excavations

(inv. number 353) [fig. 6:3]

Dating: EB II

Material: stone (type unrecorded)

Context of retrieval: necropolis, Tomb D12 
State of preservation: complete

Dimensions: length $14.1 \mathrm{~cm} \times$ width $10.2 \mathrm{~cm} \times$ thickness $0.8 \mathrm{~cm}$

Bibliography: Kenyon 1960, 125, fig. 40:3

Type: macehead from Kenyon's excavations (inv. number 1449) [fig. 7]

Dating: EB II

Material: black stone (type unrecorded)

Context of retrieval: tell, Squares EIII-IV

Stratum: Phase K-J

State of preservation: half

Dimensions: diameter $5 \mathrm{~cm} \times 4.5 \mathrm{~cm}$

Bibliography: Wheeler 1982, 630, fig. 256:2

Type: stone vessel from Kenyon's excavations (inv. number 1619) [fig. 8]

\section{EARLY BRONZE III}

Type: palette from Kenyon's excavations (inv. number 3267)

Dating: EB III

Material: stone (type unrecorded)

Context of retrieval: tell, Site H

Stratum: xi

State of preservation: fragmentary

Dimensions: length $7 \mathrm{~cm} \times$ width $4 \mathrm{~cm} \times$ thickness

$2.5 \mathrm{~cm}$

Bibliography: Dorrell 1983, 559

Type: macehead from Sellin \& Watzinger's excavations [fig. 9:1]

Dating: EB III

Material: stone (type unrecorded)

Context of retrieval: tell, northern plateau

Stratum: unrecorded

State of preservation: complete

Dimensions: length $5.6 \mathrm{~cm} \times$ diameter $4.4 \mathrm{~cm}$

Bibliography: Sellin - Watzinger 1913, fig. 110

Type: macehead from Kenyon's excavations (inv. number 1781) [fig. 9:2]

Dating: EB III

Material: stone (type unrecorded)

Context of retrieval: tell, Trench II

Stratum: XX.lxvii-lxviii

State of preservation: fragmentary

Dimensions: preserved length $5 \mathrm{~cm} \times$ diameter $6.2 \mathrm{~cm}$

Bibliography: Holland 1983, 804, fig. 365:3

Type: macehead from Kenyon's excavations (inv. number 1048) [fig. 9:3]

Dating: EB III

Material: stone (type unrecorded)

Context of retrieval: tell, Trench I

Stratum: XXXVIII.xlvii

State of preservation: fragmentary
Dating: EB II

Material: fine polished limestone

Context of retrieval: tell, Squares EIII-IV

Stratum: Phase H

State of preservation: fragmentary

Dimensions: rim diameter $16 \mathrm{~cm}$, thickness $0.3 \mathrm{~cm}$

Bibliography: Dorrell 1983, 554, 556, fig. 229:17

Type: stone vessel from Kenyon's excavations

(inv. number 1507)

Dating: EB II

Material: fine polished limestone

Context of retrieval: tell, Squares EIII-IV

Stratum: Phase Gi

State of preservation: half

Bibliography: Dorrell 1983, 554, 556, pl. 19a

Dimensions: preserved length $7.4 \mathrm{~cm} \times$ diameter 5.9

$\mathrm{cm}$

Bibliography: Holland 1983, 804, fig. 365:4

Type: macehead from Kenyon's excavations (inv. number 2922) [figs. 9:4, 10]

Dating: EB III

Material: pink streaky marble

Context of retrieval: tell, Site $\mathrm{H}$

Stratum: ix

State of preservation: complete

Dimensions: length $7 \mathrm{~cm} \times$ diameter $6.2 \mathrm{~cm}$

Bibliography: Holland 1983, fig. 804, 365:5

Type: macehead from Kenyon's excavations (inv. number 151) [fig. 9:5]

Dating: EB III

Material: calcite/Egyptian alabaster

Context of retrieval: necropolis, Tomb F2

State of preservation: complete

Dimensions: length $10.8 \mathrm{~cm} \times$ diameter $9 \mathrm{~cm}$

Bibliography: Kenyon 1960, 171, fig. 66:4

Type: macehead from Kenyon's excavations (inv. number 1593) [fig. 9:6]

Dating: EB III

Material: stone (type unrecorded)

Context of retrieval: tell, Squares EIII-IV

Stratum: Phase Ci

State of preservation: complete

Dimensions: length $7.2 \mathrm{~cm} \times$ diameter $6.2 \mathrm{~cm}$ Bibliography: Holland 1983, 806, fig. 365:10

Type: macehead from Kenyon's excavations (inv. number 611) [fig. 9:7]

Dating: EB III

Material: stone (type unrecorded) 
Context of retrieval: tell, Squares EIII-IV

Stratum: Phase Ci

State of preservation: fragmentary

Dimensions: reconstructed length $8.6 \mathrm{~cm} \times$ diameter

$7.7 \mathrm{~cm}$

Bibliography: Holland 1983, 806, fig. 365:11

Type: macehead from Kenyon's excavations (inv. number 311) [fig. 9:8]

Dating: EB III

Material: stone (type unrecorded)

Context of retrieval: tell, Trench I

Stratum: XXXVIII.xlviii-xlix

State of preservation: fragmentary

Dimensions: reconstructed length $4.3 \mathrm{~cm} \times$ diameter

$4.8 \mathrm{~cm}$

Bibliography: Holland 1983, 804, fig. 365:7

Type: macehead from Kenyon's excavations (inv. number 1116) [fig. 9:9]

Dating: EB III

Material: black stone (type unrecorded)

Context of retrieval: tell, Trench I

Stratum: XXXVII.xlvia

State of preservation: half

Dimensions: $5.8 \mathrm{~cm} \times$ diameter $5 \mathrm{~cm}$

Bibliography: Wheeler 1982, 630, fig. 256:1

Type: macehead from Kenyon's excavations (inv. number 444) [fig. 9:10]

Dating: EB III

Material: stone (type unrecorded)

Context of retrieval: tell, Trench I

Stratum: XXXVIII.xlviii-xlix

State of preservation: complete

Dimensions: length $3.8 \mathrm{~cm} \times$ diameter $4 \mathrm{~cm}$

Type: macehead from Kenyon's excavations

(inv. number 3194)

Dating: EB III

Material: fine-grained dark grey stone (type unrecorded)

Context of retrieval: tell, Site $\mathrm{H}$

Stratum: viiia

State of preservation: complete

Dimensions: diameter $6 \mathrm{~cm}$

Bibliography: Holland 1983, 806

Type: macehead from Kenyon's excavations

(inv. number 710)

Dating: EB III

Material: black and white mottled limestone

Context of retrieval: tell, Square MI

Stratum: viiia

State of preservation: half

Dimensions: unrecorded

Bibliography: Holland 1983, 80

\section{REFERENCES}

AMIRAN R.

1970 The Egyptian stone vessel from 'Ai: Israel Exploration Journal 20 (1970), pp. 170-179.

Amiran, R. - ILAN, O.

1992 Arad, eine 5000 Jahre alte Stadt in der Wüste Negev, Israel, Hamburg 1992.

AMIRAN, R. - VAN DEN BRINK, E.C.M.

2001 A comparative study of the Egyptian pottery from Tal Ma'ahaz, Stratum I: S.R. WOLFF (ed.), Studies in the Archaeology of Israel and Neighboring Lands in Memory of Douglas L. Esse (Studies in Ancient Oriental Civilizations 59), Chicago 2001, pp. 29-58.

2002 The Ceramic Assemblage from Tel Ma'ahaz, Stratum I (Seasons 1975-1976): E.C.M. VAN DEN BRINK - T.E. LEVY (eds.), Egypt and the Levant. Interrelations from the $4^{\text {th }}$ through the Early $3^{\text {rd }}$ Millennium B.C.E., London - New York 2002, pp. 273-279.

AMIRAN, R. ET ALII

1978 Early Arad. The Chalcolithic Settlement and Early Bronze City, I. First - Fifth Seasons of Excavations, 1962-1966 (Judean Desert Studies), Jerusalem 1978.

Aston, B.G.

1994 Ancient Egyptian Stone Vessels: Materials and Forms, Heidelberg 1994.

Astor, B. G. - Harrell, J. A. - ShAw, I.

2000 Stone: P.T. Nicholson - I. Shaw (eds.), Ancient Egyptian Materials and Technology, Cambridge 2000, pp. 5-77. 
BEN-TOR, A

1975a Two Burials Caves of the Proto-Urban Period at Azor: Qedem 1 (1975), pp. 1-54.

1975b The First Season of Excavations at Tell Yarmuth: August 1970: Qedem 1 (1975), pp. 5587.

BLISS, F.J.

1894 A Mound of Many Cities; or Tell el Hesy Excavated, London 1894.

BOURKE, S. ET ALII

1994 Preliminary Report on the University of Sydney's Fourteen Season of Excavations at Pella (Tabaqat Fahl) in 1992: Annual of the Department of Antiquities of Jordan 38 (1994), pp. 81-126.

BRAUN, E.

2004 Early Beth Shan (Strata XIX-XIII): G. M. FitzGerald's Deep Cut on the Tell (University Museum Monograph 121), Philadelphia 2004.

2011 Early Interactions between Peoples of the Nile Valley and the Southern Levant: E. TEETER (ed.), Before the Pyramids. The origins of Egyptian Civilization (Oriental Institute Museum Publications 33), Chicago 2011, pp. 105-122.

BRAUN, E. - VAN DEN BRINK, E.C.M.

2008 Appraising South Levantine-Egyptian interaction: recent discoveries from Israel and Egypt: B. Midant-ReYnes - Y. Tristant (eds.), Egypt at its Origins 2. Proceedings of the Third International Conference "Origin of the State. Predynastic and Early Dynastic Egypt”, Toulouse (France), $5^{\text {th }}-8^{\text {th }}$ September 2005 (Orientalia Lovaniensia Analecta 172), Leuven - Paris - Dudley 2008, pp. 643-680.

BRAUN, E. ET ALII

2001 New Evidence for Egyptian Connections During a Late Phase of Early Bronze I from the Soreq Basin in South-Central Israel: S.R. WolfF (ed.), Studies in the Archaeology of Israel and Neighboring Lands in Memory of Douglas L. Esse (Studies in Ancient Oriental Civilizations 59), Chicago 2001, pp. 59-98.

CALlaway, J.

1972 The Early Bronze Age Sanctuary at Ai (et-Tell). A Report of the Joint Archaeological Expedition to Ai (et-Tell). No. I (Colt Archaeological Institute Publications), London 1972.

DAVIES, W.

1981 The foreign Relations of Pre-Dynastic Egypt I: Egypt and Palestine in the Pre-Dynastic Period: The Journal of the Society for the Study of Egyptian Antiquities 11 (1981), pp. 2127.

DORRELL, P.G.

1983 Appendix A. Stone Vessels, Tools, and Objects: K.M. KenYon - T.A. Holland, Excavations at Jericho. Volume Five. The Pottery Phases of the Tell and Others Finds, London 1983, pp. 485-575.

ENGBERG, R.M. - SHIPTON, G.M.

1934 Notes on the Chalcolithic and Early Bronze Age Pottery of Megiddo (Studies in Ancient Oriental Civilizations 10), Chicago 1934.

EsSE, D.

1989 Secondary State Formation and Collapse in Early Bronze Age Palestine: P. DE MiroschedjI (ed.), L'urbanisation de la Palestine à l'âge du Bronze ancien. Bilan et perspectives des recherches actuelles. Actes du Colloque d'Emmaüs (20-24 octobre 1986) (British Archaeological Reports International Series 527), Oxford 1989, pp. 81-95. 
FISCHER, $\mathrm{P}$.

2002 Egyptian-Transjordanian Interaction during Predynastic and Protodynastic Times: The Evidence from Tell Abu al-Kharaz, Jordan Valley: E.C.M. VAN DEN BRINK - T.E. LEVY (eds.), Egypt and the Levant. Interrelations from the $4^{\text {th }}$ through the Early $3^{\text {rd }}$ Millennium B.C.E., London - New York 2002, pp. 323-333.

FITZGERALD, G.M.

1935 The Earliest Pottery of Beth-Shan: The Museum Journal 24 (1935), pp. 5-32.

GARSTANG, J.

1932 Jericho: City and Necropolis: Liverpool Annals of Archaeology and Anthropology 19 (1932), pp. 3-22, 35-54.

GARSTANG, J. ET ALII

1936 Jericho: City and Necropolis (Report for the Sixth and Concluding Season, 1936): Liverpool Annals of Archaeology and Anthropology 23 (1936), pp. 67-100.

GOPHNA, R.

1990 The Egyptian Pottery of 'Ein Besor: Tel Aviv 17 (1990), pp. 144-162.

GOREN, Y. - ILAN, O.

2003 The Egyptianized Pottery Vessels of Early Bronze Age Megiddo: Tel Aviv 30 (2003), pp. 42-53.

GREENBERG, R. - EISENBERG, E.

2002 Egypt, Bet Yerah and Early Canaanite Urbanization: E.C.M. VAN DEN BRINK - T.E. LEVY (eds.), Egypt and the Levant. Interrelations from the $4^{\text {th }}$ through the Early $3^{\text {rd }}$ Millennium B.C.E., London - New York 2002, pp. 213-222.

GREENBERG, R. ET ALII

2012 Tel Beth Yerah: Hub of the Early Bronze Age Levant: Near Eastern Archaeology 75 (2012), pp. 88-107.

GreEnBERG, R. - Wengrow, D. - PAZ, S

2010 Cosmetic Connections? An Egyptian Relief Carving from Early Bronze Age Tel Bet Yerah (Israel): Antiquity (Project Gallery) 324/84 (2010) (http://www.antiquity.ac.uk/ projgall/greenberg324/).

HARRISON, T.H.

1993 Economics with an Entrepreneurial Spirit: Early Bronze Age Trade with Late Predynastic Egypt: The Biblical Archaeologist 56 (1993), pp. 81-93.

HELCK, W.

1971 Die Beziehungen Ägyptens zu Vorderasien im 3. Und 2. Jahrtausend v. Chr. (Ägyptologische Abhandlungen 5), Wiesbaden 1971.

HENNESSY, J.B.

1967 The Foreign Relations of Palestine during the Early Bronze Age, London 1967.

HOLLAND, T.A.

1982 Appendix C. Figurines and Miscellaneous Objects: K.M. KenYON - T.A. Holland, Excavations at Jericho. Volume Four. The Pottery Type Series and Other Finds, London 1982, pp. 551-563.

1983 Appendix M. Stone Maceheads: K.M. KENYON - T.A. Holland, Excavations at Jericho. Volume Five. The Pottery Phases of the Tell and Others Finds, London 1983, pp. 804 813

JACOBS, P.

1996 A cosmetic palette from Early Bronze Age III at Tell Halif: J.D. SEGER (ed.), Retrieving the past: essays on archaeological research and methodology in honor of Gus W. van Beek, Winona Lake 1996, pp. 123-134. 
JOFFE, A.H

2000 The Early Bronze Age Pottery from Area J: I. FinKELSTEIN - D. UsSISHKIN - B. HALPERN (eds.), Megiddo III. The 1992-1996 Seasons (Tel Aviv Monograph Series 18), Tel Aviv KENYON, K.M 2000, pp. 161-185.

1960 Excavations at Jericho. Volume One. The Tombs excavated in 1952-1954, London 1960.

1965 Excavations at Jericho. Volume Two. The Tombs excavated in 1955-1958, London 1965.

KENYON, K.M. - Holland, T.A.

1983 Excavations at Jericho. Volume Five. The Pottery Phases of the Tell and Others Finds, London 1983.

KLEMM, R. - KLEMM D.D.

$2008 \quad$ Stones and Quarries in Ancient Egypt, London 2008.

KOCHAVI, M.

1981 The History and Archaeology of Aphek-Antipatris: A Biblical City in the Sharon Plain: KROEPER, K. Biblical Archaeologist 44 (1981), pp. 75-86.

1996 Minshat Abu Omar: Burials with Palettes: J. SPENCER (ed.), Aspects of Early Egypt, London 1996, pp. 70-92.

LAPP, N.

2003 Cylinder Seals, Impressions, and Incised Sherds: W.E. RAST - R.T. SchAuB, Bâb edhDhrâ': Excavations at the Town Site (1975-1981). Part 1: Text, Part 2: Plates and Appendices (Reports of the Expedition to the Dead Sea Plain, Jordan, Volume II), Winona Lake 2003, pp. 522-565.

LEE, J.R

2003 Worked Stones: W.E. RAST - R.T. ScHAUB, Bâb edh-Dhrâ': Excavations at the Town Site (1975-1981). Part 1: Text, Part 2: Plates and Appendices (Reports of the Expedition to the Dead Sea Plain, Jordan, Volume II), Winona Lake 2003, pp. 622-637.

LEVY, T. ET ALII

2002 The Protodynastic/Dynasty 1 Egyptian Presence in Southern Canaan: A Preliminary Report on the 1994 Excavations at Nahal Tillah, Israel: E.C.M. VAN DEN BRINK - T.E. LEVY (eds.), Egypt and the Levant. Interrelations from the $4^{\text {th }}$ through the Early $3^{\text {rd }}$ LILYQUiST, C. Millennium B.C.E., London - New York 2002, pp. 411-445.

1995 Egyptian Stone Vessels: Khian Through Tuthmosis IV, New York 1995.

LOUD, G.

1948 Megiddo II. Seasons of 1935-39 (Oriental Institute Publications 62), Chicago 1948. LOVELL, J.L.

2008 Horticulture, status and long-range trade in Chalcolithic Southern Levant: early connections with Egypt: B. MidANT-ReYNES - Y. TRISTANT (eds.), Egypt at its Origins 2. Proceedings of the Third International Conference "Origin of the State. Predynastic and Early Dynastic Egypt", Toulouse (France), $5^{\text {th }}-8^{\text {th }}$ September 2005 (Orientalia Lovaniensia Analecta 172), Leuven - Paris - Dudley 2008, pp. 741-762.

MĄCZYŃKA, A.

2008 Some remarks on Egyptian-Southern Levantine interrelations in the first half of $4^{\text {th }}$ millennium BC: B. MidAnt-Reynes - Y. Tristant (eds.), Egypt at its Origins 2. Proceedings of the Third International Conference "Origin of the State. Predynastic and Early Dynastic Egypt”, Toulouse (France), $5^{\text {th }}-8^{\text {th }}$ September 2005 (Orientalia Lovaniensia Analecta 172), Leuven - Paris - Dudley 2008, pp. 763-781. 
MARQUET-KRAUSE, J.

1949 Les fouilles de 'Ai (et-Tell) 1933-1935. La résurrection d'une grande cité biblique (Bibliothèque archéologique et historique 45), Paris 1949.

MacDonald, E. - StARKEY, J.L. - HARDing, G.L.

1932 Beth Pelet II (Publication of the Egyptian Research Account 52), London 1932.

DE MiroschedJi, P.

1992 Une palette Egyptienne prédynastique du sud de la plain côtière d'Israël: Eretz Israel 23 (1992), pp. 90*-94*.

2002 The socio-political dynamics of Egyptian-Canaanite interaction in the Early Bronze Age: E.C.M. VAN DEN BRINK - T.E. LEVY (eds.), Egypt and the Levant. Interrelations from the $4^{\text {th }}$ through the Early $3^{\text {rd }}$ Millennium B.C.E., London - New York 2002, pp. 39-57.

2012 Egypt and Southern Canaan in the Third Millennium BCE: Uni's Asiatic Campaigns Revisited: M. Gruber - S. Ahituv - G. Lehmann - Z. TAlshir (eds.), All the Wisdom of the East. Studies in Near Eastern Archaeology and History in Honor of Eliezer D. Oren (Orbis Biblicus et Orientalis 255), Fribourg 2012, pp. 265-292.

DE MirosCHEDJI, P. ET ALII

1988 Yarmouth 1. Rapport sur les trois premières campagnes de fouilles à Tel Yarmouth (Israël) (1980-1982) (Éditions Recherche sur les Civilisations, Mémoire 76), Paris 1988.

2001 Les fouilles de Tell es-Sakan (Gaza): nouvelles données sur les contacts égyptocananéens aux IVe-IIIe millénaires: Paléorient 27.2 (2001), pp. 75-104.

NigRO, L.

2005 Tell es-Sultan/Gerico alle soglie della prima urbanizzazione: il villaggio e la necropoli del Bronzo Antico I (3300-3000 a.C.) (Rome "La Sapienza" Studies on the Archaeology of Palestine \& Transjordan 1), Roma 2005.

2007 Aside the spring: Byblos and Jericho from village to town in the second half of the 4th millennium BC: L. Nigro (ed.), Byblos and Jericho in the Early Bronze I. Social dynamics and cultural interactions. Proceedings of the International Workshop held in Rome on March 6 2007 by Rome "La Sapienza" University (Rome «La Sapienza» Studies on the Archaeology of Palestine \& Transjordan 4), Roma 2007, pp. 1-45.

2008 Tell es-Sultan/Jericho from Village to Town: A Reassessment of the Early Bronze Age I Settlement and Necropolis: J.M. CóRdOBA ET ALII (eds.), Proceedings of the $5^{\text {th }}$ International Congress on the Archaeology of the Ancient Near East (5-8 April 2006), Madrid 2008, Volume II, pp. 645-662.

2010 Tell es-Sultan/Jericho in the Early Bronze II (3000-2700 BC): the rise of an early Palestinian city. A synthesis of the results of four archaeological expeditions (Rome «La Sapienza» Studies on the Archaeology of Palestine \& Transjordan 5), Rome 2010.

NigRo, L. - SALA, M.

2012 Preliminary Report of the Sixth Season (2011) of Excavations by the University of Rome "La Sapienza" at Khirbat al-Batrāwī (Upper Wādī az-Zarqā'): Annual of the Department

Petrie, F.

1953 Ceremonial slate palettes, London 1953.

Polcaro, A.

2005 La Tomba A: interpretazione della sequenza stratigrafica e del rituale funerario: L. NIGRO, Tell es-Sultan/Gerico alle soglie della prima urbanizzazione: il villaggio e la necropoli del Bronzo Antico I (3300-3000 a.C.) (Rome "La Sapienza" Studies on the Archaeology of Palestine \& Transjordan 1), Roma 2005, pp. 49-70. 
RAST, W.E. - SCHAUB, R.T.

1989 Bâb edh-Dhrâ': Excavations in the Cemetery directed by Paul W. Lapp (1965-67) (Reports of the Expedition to the Dead Sea Plain, Jordan, Volume I), Winona Lake 1989.

2003 Bâb edh-Dhrâ': Excavations at the Town Site (1975-1981). Part 1: Text, Part 2: Plates and Appendices (Reports of the Expedition to the Dead Sea Plain, Jordan, Volume II), Winona Lake 2003.

SALA, M

2005 Le produzioni ceramiche gerichiote del Bronzo Antico I: materiali stratificati provenienti dal tell: L. NigRo, Tell es-Sultan/Gerico alle soglie della prima urbanizzazione: il villaggio e la necropoli del Bronzo Antico I (3300-3000 a.C.) (Rome "La Sapienza" Studies on the Archaeology of Palestine \& Transjordan 1), Roma 2005, pp. 167-196.

2008 L'architettura sacra della Palestina nell'età del Bronzo Antico I-III (Contributi e Materiali di Archeologia Orientale 13), Roma 2008.

SELlin, E. - WATZINGER, C.

1913 Jericho. Die Ergebnisse der Ausgrabungen (Wissenschaftliche Veröffentlichung der Deutschen Orient-Gesellschaft 22), Leipzig 1913.

SHAW, I.

2010 Hatnub: Quarrying Travertine in Ancient Egypt (Eighty-Eight Excavation Memoir), London 2010.

SOWADA, K.N.

2000 Egyptian Palettes in the EB II and EB III Canaan: P. MAtTHIAE ET ALII (eds.), Proceedings of the First International Congress on the Archaeology of the Ancient Near East, Roma 2000, pp. 1527-1540.

2009 Egypt in the Eastern Mediterranean during the Old Kingdom. An Archaeological Perspective (Orbis Biblicus et Orientalis 237), Fribourg 2009.

SPARKS, R.T.

2003 Egyptian Stone Vessels and the Politics of Exchange (2617-1070 BC): R. MATTHEws - C.

TALBOT, G.C.

ROOMER (eds.), Ancient Perspective on Egypt, London 2003, pp. 39-56.

1983 Beads and Pendants from the Tell and Tombs: K.M. KEnYON - T.A. Holland, Excavations at Jericho. Volume Five. The Pottery Phases of the Tell and Others Finds, London 1983, pp. 788-801.

TEETER. E. (ed.)

2011 Before the Pyramids. The origins of Egyptian Civilization (Oriental Institute Museum TuFNELL, O. Publications 33), Chicago 2011.

1958 Lachish IV, The Bronze Age (The Wellcome-Marston Archaeological Research DE VAUX, R Expedition to the Near East, Vol. IV), London 1958.

1949 La deuxième champagne de fouilles à Tell el-Far'ah près Naplouse: Revue Biblique 56 (1949), pp. 102-138.

WENGROW, D.

2006 The archaeology of Early Egypt. Social transformations in north-east Africa, 10,000 to 2650 BC, Cambridge 2006.

WHEELER, M.

1982 Appendix F. Loomweights and Spindle Whorls”: K.M. KENYON - T.A. HOLLAND, Excavations at Jericho. Volume Four. The Pottery Type Series and Other Finds, London 1982, pp. 623-637. 
WILKINSON, A.

1989 Objects from the Early Bronze II and III Tombs: W.E. RAST - R.T. ScHAUB, Bâb edhDhrâ': Excavations in the Cemetery directed by Paul W. Lapp (1965-67) (Reports of the Expedition to the Dead Sea Plain, Jordan, Volume I), Winona Lake 1989, pp. 444-470.

YANNAI, E.

2002 Imported Finds from the 'Ein Assawir Tombs (Israel) and Their Significance in Understanding the Chronological Synchronization between Israel, Egypt, and Eastern Anatolia: E.C.M. VAN DEN BRINK - T.E. LEVY (eds.), Egypt and the Levant. Interrelations from the $4^{\text {th }}$ through the Early $3^{\text {rd }}$ Millennium B.C.E., London - New York 2002, pp. 334345 . 


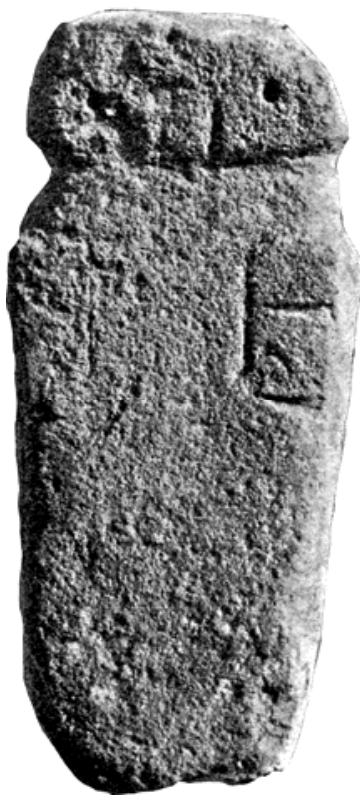

Fig. 1: EB I Egyptian palette from Sellin and Watzinger's excavations (after Sellin - Watzinger 1913, fig. 107).

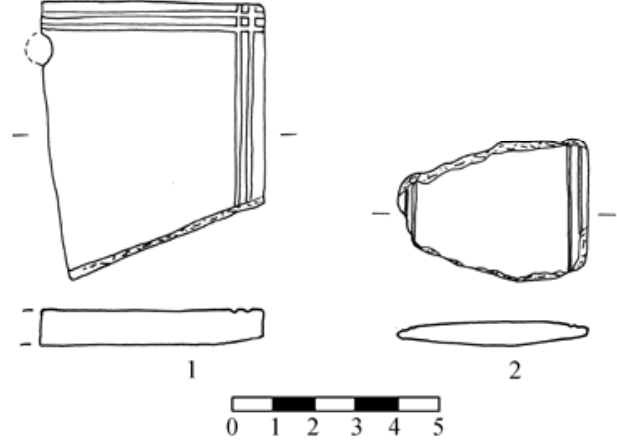

Fig. 2: Egyptian palettes from EB I contexts. 1, palette from Garstang's North-Eastern Trench (redrawn from Garstang et al. 1936, pl. XXXVI:26); 2, palette Kenyon's Trench III (redrawn from Holland 1982, fig. 226:16).

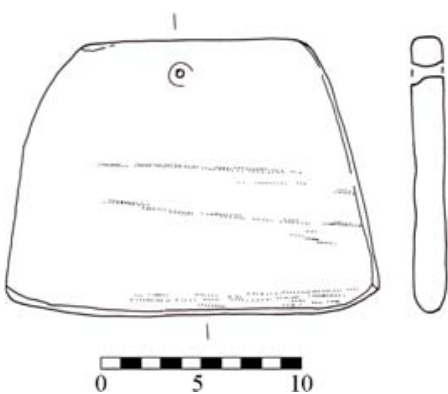

Fig. 3: EB IB Egyptianizing palette from Kenyon's Trench III (redrawn from Dorrell 1983, fig. 230:13). 


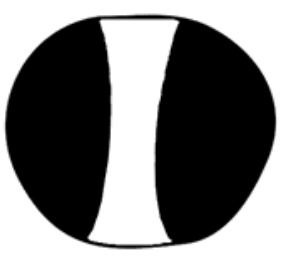

1

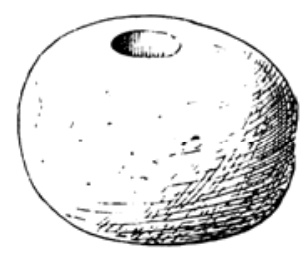

2

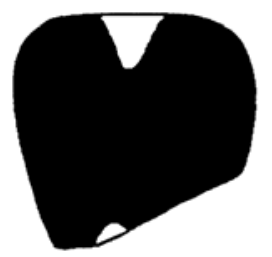

5

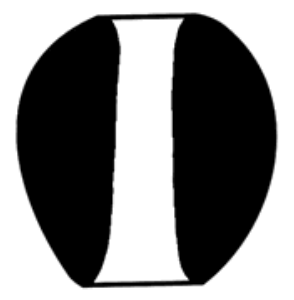

6
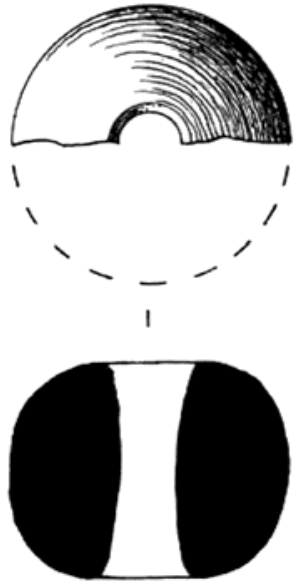

3

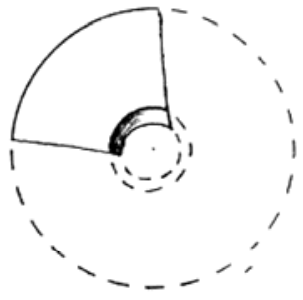

I

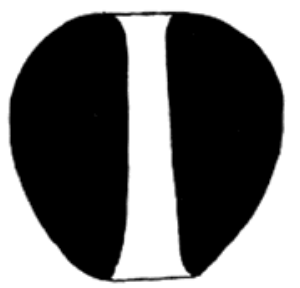

7

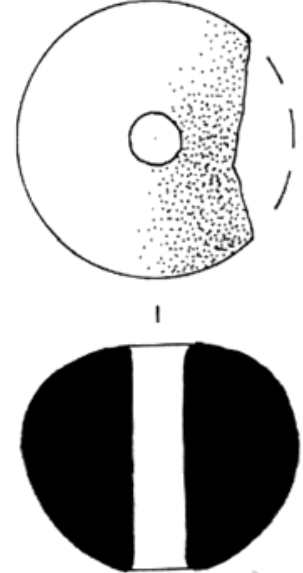

4

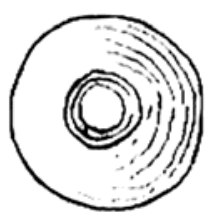

1

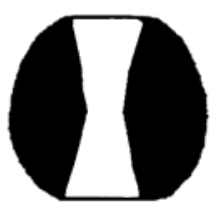

8

0

Fig. 4: Maceheads from EB I contexts. 1, macehead from Garstang's North-Eastern Trench (after Garstang et al. 1936, pl. XXXVI:25); 2, macehead from Sellin and Watzinger's excavation's (after Sellin - Watzinger 1913, fig. 109); 3, macehead from Kenyon's Square MI (after Holland 1983, 804, fig. 365:6); 4, macehead from Kenyon's Trench III (after Holland 1983, 804, fig. 365:1); 5, macehead from Garstang's North-Eastern Trench (after Garstang et al. 1936, pl. XXXVI:24); 6, macehead from Garstang's Tomb A (after Garstang 1932, pl. VII:5); 7, macehead from Kenyon's Square MI (after Holland 1983, 804, fig. 365:2); 8, macehead from Kenyon's Tomb K2 (after Kenyon 1965, fig. 5:8). 


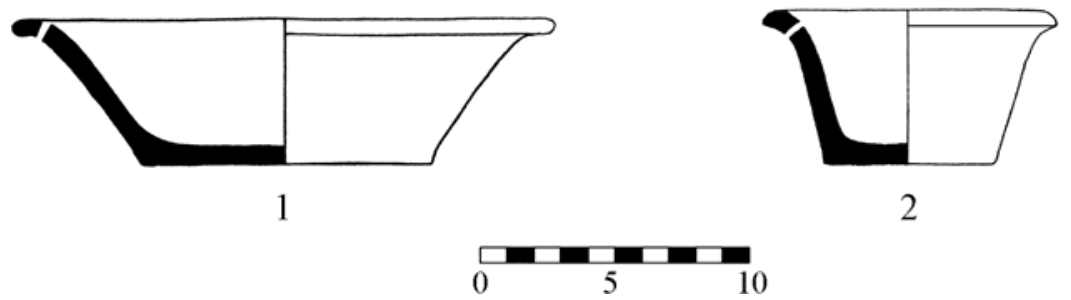

Fig. 5: EB IA lotus vases from Jericho necropolis, Tomb A114 (after Kenyon 1960, fig. 17:23) and Tomb K1 (after Kenyon 1965, fig. 12:6).
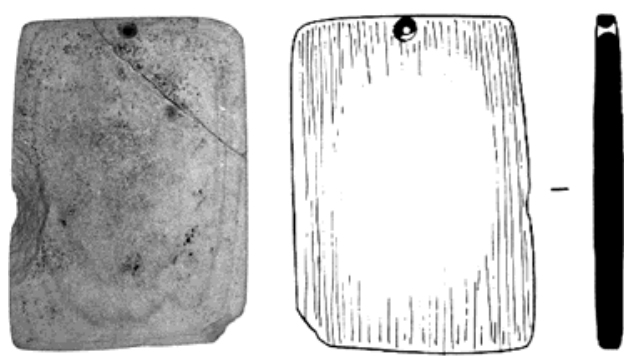

1

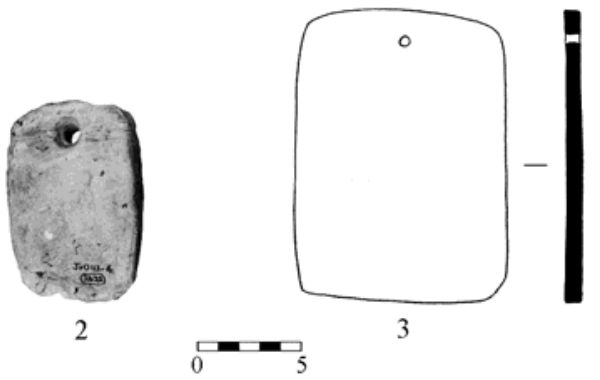

Fig. 6: EB II Egyptianizing palettes. 1, palette from Kenyon's Squares EIII-IV (after Dorrell 1983, fig. 230:12); 2, palette from Kenyon's Trench II (after Dorrell 1983, 559, pl. 21:c); 3, palette from Kenyon's Tomb D12 (after Kenyon 1960, fig. 40:3)

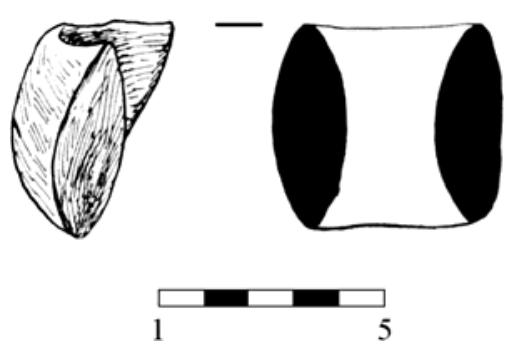

Fig. 7: Macehead from EB II context in Kenyon's Squares EIIIIV (after Wheeler 1982, fig. 256:2).

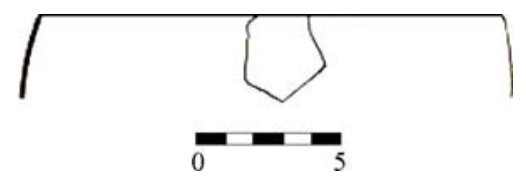

Fig. 8: Stone vessel from EB II context in Kenyon's Squares EIIIIV (after Dorrell 1983, fig. 229:17). 


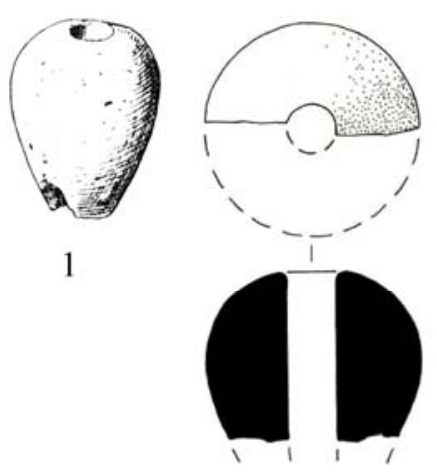

2

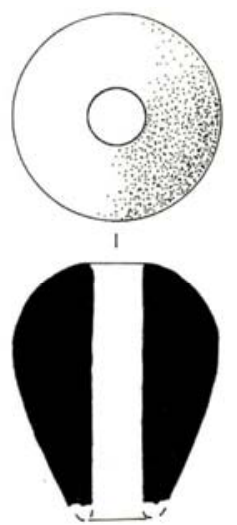

3

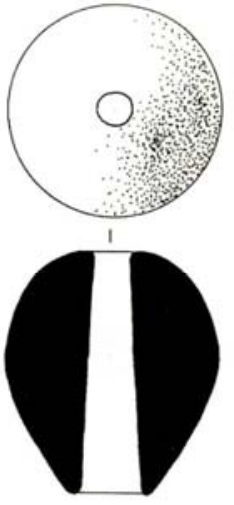

4

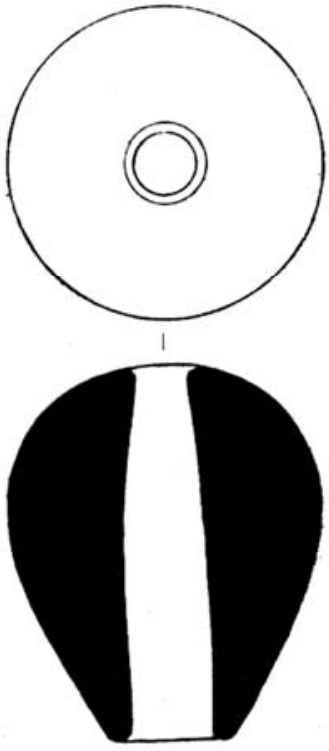

5

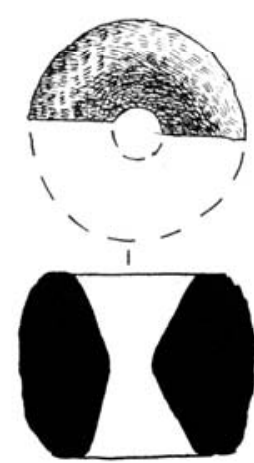

9

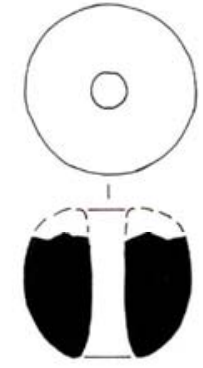

8

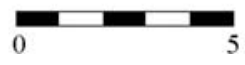

Fig. 9: Maceheads from EB III contexts. 1, macehead from Sellin and Watzinger's excavation (after Sellin - Watzinger 1913, fig. 110); 2, macehead from Kenyon's Trench II (after Holland 1983, fig. 365:3); 3, macehead from Kenyon's Trench I (after Holland 1983, fig. 365:4); 4, macehead from Kenyon's Site H (after Holland 1983, fig. 365:5); 5, macehead from Kenyon's Tomb F2 (after Kenyon 1960, 171, fig. 66:4); 6, macehead from Kenyon's Squares EIII-IV (after Holland 1983, fig. 365:10); 7, macehead from Kenyon's Squares EIII-IV (after Holland 1983, fig. 365:11); 8, macehead from Kenyon's Trench I (after Holland 1983, fig. 365:7); 9, macehead from Kenyon's Trench I (after Wheeler 1982, fig. 256:1); 10, macehead from Kenyon's Trench I (after Holland 1983, fig. 365:13). 
Maura Sala

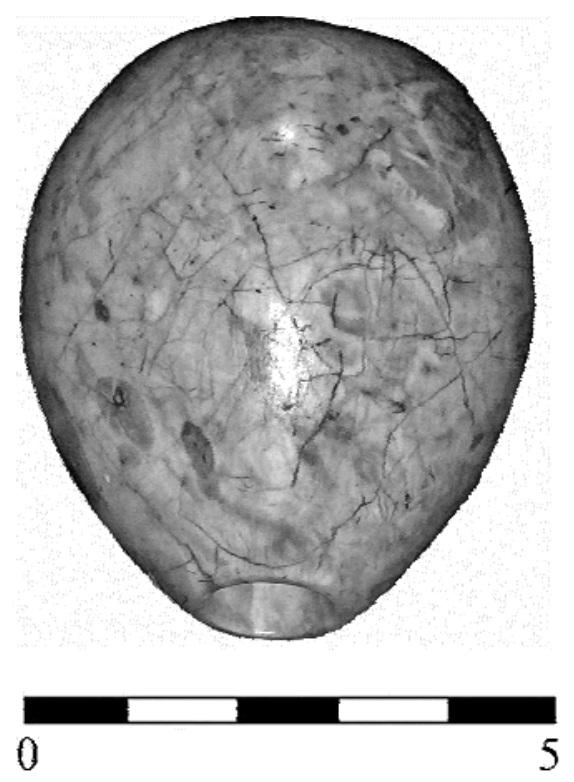

VO

Fig. 10. Pink marble macehead 2922 from Kenyon's Site H. 